\title{
SOCIAL ADAPTATION OF MILITARY SERVICEMEN, DISCHARGED FROM MILITARY SERVICE, IN DYNAMIC SOCIAL ENVIRONMENT
}

\author{
Venelin Terziev \\ Academician of the Russian Academy of Natural History, Moscow, Russia, Prof. \\ D.Sc. (Ec.), D.Sc. (National Security), D.Sc. (Social Activities), Ph.D., National Military University, \\ Veliko Tarnovo, Bulgaria; University of Rousse, Rousse, Bulgaria, terziev@skmat.com
}

\begin{abstract}
The process of social adaptation of discharged servicemen requires the application of integrated approaches embracing different aspects and elements. Current study presents a competence model for social adaptation of discharged servicemen in Bulgaria as an example. It provides important implications on the concept of competences acquiring and the application of lifelong learning. The model is built on the basis of identifying key competencies as a starting point in accordance to contemporary trends, social and educational policies. Thus it appears to be feasible and could be successfully developed and applied into the practice.
\end{abstract}

Keywords: social adaptation, military servicemen, social environment.

\section{SOCIAL ADAPTATION OF MILITARY SERVICEMEN, DISCHARGED FROM MILITARY SERVICE, IN DYNAMIC SOCIAL ENVIRONMENT}

Dynamic changes in security environment pose serious challenges to military servicemen,discharged for one or another reason from military service, and their families. With transferring from the military to the civil sociumin their conditions of life,occur some essential changes, affecting various aspects of life: geography of the service and residence, living conditions, nature of activity, social status, level of claims to a new life, prospects for further development,circle of socialization, etc. What impresses here, is that the in the basis of all these changes lie mainly changes in the psychology of the personality of the particular individual, leaving his usual sociumand entering into an unfamiliar one.

Researches in this area are not so popular and this provokes our scientific searches to uncover the factors affecting the psychological state of the modern Bulgarian military serviceman, passing in the reserve, and his professional adaptation, corresponding to the new conditions of life. Researches in this direction lead us to the manifestation of several major groups of factors underlying the psychological state of the discharged from military service serviceman. These include: the state of the economy at the present stage; the willingness of civil society to „adopt” the passing in the reserve servicemen and the members of their 
families; the degree of commitment (attitude) of the Ministry of Defense to this category; realized by the Ministry of Labor and Social Policy social policies towards this risk group in the labor market.

As a consequence of their manifestation, resulting key issues can be defined, such as:

- Problems,stemming from the radical change of the whole way of life: moving to a new place of residence; deterioration of the financial status; loss of housing and insecurity of the possibility of acquiring one at the new location; problems with finding a job and need to prepare for life in the new conditions;

- Problems from lack of guaranteed employment after the service, imperfections of the system for vocational training and retraining of military servicemen from the reserve, problems with finding job for them; insufficient practical exercising of the privileges and rights of servicemen, discharged from the Bulgarian army;

- Problems from retaining previous stereotypes of action by many servicemen before and after the release, associated with the expectationsfor support from the state; the habit of relying on formalized social protection of the military structure;

- Problems from unpreparedness for action in the new economic situation; loss of qualification of members of the families of servicemen; persistently negative image of the discharged from military service servicemen in the opinion of the staff of civil organizations;

- Problems from the open ignoring by the authorities of the military governing body at different levels (with the exception of military district offices) of the needs of the discharged from military service servicemen; unwillingness of the Ministry of Defense to participate in solving their problems after discharge from military service, etc.

The analysis shows that for a significant part of the servicemen and the members of their families, the dischargefrom the army leads to the collapse of many hopes, the loss of perspective in life and development. People who, from a young age, devote themselves to the difficult military service, as a rule have difficulties to adapt to the new conditions. Socio-psychological adaptation becomes for them a complicated process. The need to adopt new social roles, to form a new identity, which to allow for an adequate self-perception, new environment, acquiring new profession. Moreover that these difficulties accompany the discharged from military service servicemen through the whole process of social adaptation. They find it difficult to navigate in the world of civil professions and sources of information, to compare their capabilities with the requirements of different types of work, to seek vacancies and conclude contracts (creation of suitable employment relationship).

As a result of all this, the people capable of making a worthy contribution to the restructuring of society, find themselves a part of a socially unprotected category and constitute a group of risk. Studies are indicative that serious difficulties with the choice of civil profession experience up to $70 \%$ of the servicemen from the reserve (data of the Employment Agency). Many of them remain unemployed up to a year and more.Apart from finding work for an adequate entry of the servicemen, discharged from military service, in the world of civilian life, a lot of complex work is necessary from the side of the servicemen themselves: they need in many ways to change their perception of themselves, of their inner world and the world around them, to adopt new strategies and tactics of behavior (new behavioral model).

The discharged from military service, as no other category of citizens are in needed of quality professional consultation assistance on all matters related to job search (recruitment), passing retraining(professional requalification), adaptation to the labor market and the new workplace. Unfortunately, this kind of training is not carried out today nor in military units nor by military district offices of residence, neither the state social services offer adequate programs and measures in this direction.

For the purpose of development and implementation of such projects within the Program for social adaptation of military servicemen, the general and private technologies of social adaptation of servicemen from the reserve and members of their families are used. They include the technologies of vocational orientation, psychological rehabilitation, socio-psychological rehabilitation, socio-pedagogical adaptation, attracting to small businesses, support of small businesses, recruitment, training and monitoring.

The main directions of psychological support are: psychological counseling, psychological corrections, professional orientation and psychotherapy, using a wide methodological range and taking into account the uniqueness of the individual, of his problems in the context of the life situation; the psychological support of entrepreneurial activity of military reservists, managers and employees of enterprises of small and medium businesses. Psychologists conduct psych diagnosis, individual counseling and psychotherapy, group psychotherapy, vocational counseling and vocational psychological selection, socio-psychological trainings 
for different purposes, primary medical diagnostics.

Accumulated experience, approbation of various consultation methods, extensive statistics gathered in the course of realization of the Social Adaptationprogram, allow to summarize the main results of psychological diagnosis of social problems of servicemen discharged from military service. On this basis it is possible to determine the moments that prevail in the structure of the psychological problems of soldiers, who passed in the reserve, and the members of their families. More specifically, these are: career guidance and job search, reluctance to take responsibility for their life situation, partial psychological maladaptation, family conflicts, weak development of communicative habits, alcohol abuse, various addictions, adaptation neurotic reactions and neuroses.

The study of psychological problems of the studied category of servicemen and members of their families, shows that the act of discharging a family member from military service, is a painful moment for all its members. With the family members, the main causes of stress conditions are: lack of work for spouses, lack of home, alcoholism of one of the spouses, material difficulties, problems with the education of children, divorces, loss of friends and relationships. As a consequence of these problems, first among psychological deviations are apathy, depression, fears, neuroses both in children and adults. Knowing these problems allows to determine the contents of the necessary social and psychological support of servicemen who passed in reserve.

Furthermore, an important part of the work in the field of psychological support is the precise analysis of all previous experience and personal qualities of officersfrom the reserve, the maximum possible account thereof when selecting a suitable job or retraining profile. Attention is paid to the following features of the discharged from military service serviceman: level of education, profile of vocational training, relevance of education and the requirements of civil activity, characteristics of professional qualities, age characteristics.

A particular group of servicemen discharged from military service, constitute the participants in peacekeeping or special missions. They usually have a pronounced manifestations of posttraumatic stress disease. The most common are: repeated vivid dreams and nightmares of combat situations, intrusive memories of psych traumatic events, occurring together with heavy experiences, sudden experiences, „returning” to the psychotraumatic situation, increased irritability, unreasonable outbursts of anger. Many of these people lose interest in public life. They show little activity in solving their own vital problems. Often withthem is observed loss of the ability to empathize and the need for spiritual intimacy with other people, including family life, is observed. The life experiences of these people is unique and differs sharply from the experience of people who have not participated in such missions. Memories and common past, bring participants together and make them seek each other. Moreover, psychological support is needed not only by the disabled in wars, but also his closest circle - parents, wife, children. Experience shows that these families even now are not considered part of the categories of families in special need and requiring protection and socio-psychological support. The approbation of the activities in these areas allows a general model for working with former servicemen and members of their families to be drawn up. No less attention in the course of implementation of the Program for Social Adaptation of servicemen deserves the fact that discharged from military service servicemen need psychological support at all stages of their transition to civilian activities. Implementation of an integrated approach to this work requires solving problems related to:

- Timely preparation for discharge from military service and transition to civilian activities;

- Informing military reservists of the regularities of the transitional period, the characteristics of the labor market, the professional activities in civilian conditions, and the difficulties awaiting them;

- Psychological readiness for change of occupation and resilience in critical situations;

- Selection of a new profession, having similarities with earlier work;

- Habits in applying the simplest methods and ways to reduce the mental strain and stress condition;

- Developing strategies and tactics of behavior in the labor market.

Experience shows that the greatest effect in the psychological adaptation of military specialists is achieved where systematic, planned work is carried out in view of the specifics of the stages of transition of the military reservists and members of their families to the new conditions of civil life. These include:

Stage of preparation for release from military service, in which, through information and informationmethodical materials on various issues related to their behavior at the stage of transition to the new conditions of life and activity, to reduce unnecessary psychological stress and certain aggressiveness in the next stages adaptation; 
Stage of vocational training, relating to readiness for the process of reorientation as a specific activity, related to the collection and analysis of information on the labor market by studying their own opportunities to acquire the necessary knowledge and skills to work, and by search of the optimum workplace for them. For this purpose psycho-diagnostic tests of professional interests and abilities shall be conducted and concrete recommendations for purposeful development of the psychological qualities of servicemen, which are professionally important for future work, shall be given. Psychological support of the process of conversion is an important component of sociopsychological adaptation of military reservists as it is directed to the formation of habits and selfmanagement of their own behavior and contributes to the formation of the activity of the person already at the stage of job placement;

Stage of job placement, the meaning of which is in the persistence and self-confidence of servicemen, discharged from military service, especially after several refusals of job placement, knowing by their own strengths and preparedness for temporary compromises in the selection of work, stemming from the situation in the labor market, knowing the existing technologies for efficient search and efficient finding of a job;

Stage of learning the new activity, in which it is necessary to show the serviceman that the mere fact of finding a job, does not put an end to the problems of entry into civil life. Before him stays a continuous and controversial process of learning new tasks and new system of relations in civil socium, which is arranged in a way far different from the military one. During this period psychologists and vocational guidance specialists help military reservists to correctly build relationships with colleagues and management, to choose the manner of behavior and interactions with others, to overcome difficulties arising with learning the new profession, to not lose heart in unsuccessful start. Their role is to help them understand that in terms of market-oriented relations, the readiness for change of the workplace should be practically constant.

Thus, as an important result that require a material adjustment to further work on social adaptation of soldiers, participating in combat actions, conclusions are made that post-traumatic phenomena develop only after the return of the individual to the normal conditions of life, after being in an extreme situation. It is at this stagethat often anadditional psycho-trauma occurs, and the already usual, so called normal conditions of peaceful life, for many of the participants in combat actions become a source of stress and negative psychological changes.

Excluding the military reservist from the system of social relations with his environment, i.e. the destruction of the structure of the created group, of those relationships, that have developed there, in an extreme situation, when these relations mean for people much more than all other values of life, acquires psychogenic nature and in conjunction with other factors, leads to social and psychological maladaptation of the individual (Terziev, 2018a, pp. 228-236; Stefanov, Terziev, Banabakova, 2018b, pp. 93-102; Stefanov, Terziev, Banabakova, 2018c, pp. 111-119; Terziev, Stefanov, Banabakova, 2018d, pp. 120-131; Terziev, Stefanov, Banabakova, 2018e, pp. 132-148; Terziev, 2018f, pp. 213-227; Terziev, 2018g, pp. 237-247; Terziev, 2018h, pp. 256-265; Terziev, 2018i, pp. 266-276; Terziev, Latyshev, Georgiev, 2018j, pp. 248-255; Glushkov, Simeonov, Georgiev, 2018k, pp. 88-92).

It is noteworthy that the social adaptation of servicemendischarged from military service is directly dependent on the professional and psychological adaptation, which requires the establishment of a comprehensive model for such adaptation. The realization of this comprehensive model of social adaptation of servicemen, discharged from military service should be carried out in different directions, one of which is their retraining in specific, required by region of residence, occupations. This direction becomes dominant in the system for their social adaptation of the Bulgarian Army.

And this in itself requires practical realization of educational programs for re-training of military reservists and members of their families, development of special courses,application of modular programs, creation of specialized training centers, etc. The process of re-trainingof the discharged from military service servicemen continuously improves in accordance with the requirements of the Bulgarian Army.

In general, the studied direction of activity can be assessed as substantial, significant, important, yet not a priority in the social adaptation of former servicemen and members of their families. Studying the experience of work in this direction, and also the experience of other countries, shows that re-training is important, but is still just one element of the process of adaptation, that acquiring of new specialty by the discharged from military service servicemen does not solve all their problems. Moreover, even the current system for their retraining is not free from significant flaws.

The main disadvantage of such approach is that in it is not realized the requirement of the famous didactic principle- for the individual and group learning approach. This approach does not imply differences in professional re-training between the former military doctor, military financier, military professor of public 
humanities and certain other categories of officers, to which a retraining of this type is, as a rule, redundant (Banabakova, Georgiev, 2017a, pp. 37-47; Banabakova, Georgiev, 2018l, pp. 462-467; Terziev, 2017b, pp.517-528; Terziev, 2017c; Hristov, 2018m, pp. 277-282; Terziev, Nichev, 2017d, p.152; Terziev, Nichev, 2017e, pp.846-850; Terziev, Nichev, 2017f, p.164; Terziev, Nichev, 2017g, pp.915-919; Terziev, Madanski, Georgiev, 2017h, pp.743-747; Terziev, Madanski, Georgiev, 2017i, pp.748-753; Terziev, Nichev, Stoyanov, Georgiev, 2017j, pp.690-694; Terziev, Latyshev, Georgiev, 2017k, pp.754-772; Terziev, Nikolay, Bogdanov, 2017l, pp.671-677; Terziev, Madanski, Kanev, 2017m, pp.1331-1346; Terziev, Madanski, Kanev, 2017n, pp.1355-1372; Terziev, Madanski, Kanev, 2017o, pp.1380-1393; Terziev, Madanski, Kanev, 2017p, pp.396415; Terziev, 2017q, pp.641-653; Terziev, Nichev, 2017r, pp.627-630; Terziev, Madanski, Kanev, 2017s, pp.575-594; Terziev, 2017t, pp.22-28; Terziev, Nichev, 2017u, pp.646-658; Terziev, Nichev, 2017v, pp.659670; Terziev, Madanski, 2017w, pp.610-625; Terziev, Madanski, 2017x, pp.917-937).

\section{CONCLUSION}

In addition, the already existing analysis shows that the interest of any civil educational institution to the matter of re-training servicemen, discharged from military service consists primarily in raising funds for the organization of the re-trading of all categories of the population. The problems of the adaptation of people to the new conditions of life, their job placement with maximum benefit to the development of the region, do not concern the educational institutions, because the function is not inherent in the latter.

Therefore, knowing the psychological and professional aspects of the adaptation of servicemen, discharged from military service and members of their families, is the basis for the creation of a methodology for social adaptation, reflecting the studied in this article aspects and achieving life balance for the studied category, according to the new conditions of life.

In line with this, we direct our study towards greater concreteness of the Bulgarian experience of social adaptation of servicemendischarged from military service.

\section{REFERENCE LIST}

Terziev, Venelin. (2018a). Building a model of social and pshychological adaptation. // ADVED 2018-4th International Conference on Advances in Education and Social Sciences Abstracts \& Proceedings, 1517 October 2018- Istanbul, Turkey, International Organization Center of Academic Research, www.ocerints.org, Istanbul, Turkey, 2018, pp. 228-236, ISBN: 978-605-82433-4-7.

Stefanov, S., Terziev, V., Banabakova, V. (2018b). The undertsanding of security in the postmodern society. // ADVED 2018- 4th International Conference on Advances in Education and Social Sciences Abstracts \& Proceedings, 15-17 October 2018- Istanbul, Turkey, International Organization Center of Academic Research, www.ocerints.org, Istanbul, Turkey, 2018, pp. 93-102, ISBN: 978-605-82433-4-7.

Stefanov, S., Terziev, V., Banabakova, V. (2018c). Levels of security and postmodern society. // ADVED 2018- 4th International Conference on Advances in Education and Social Sciences Abstracts \& Proceedings, 15-17 October 2018- Istanbul, Turkey, International Organization Center of Academic Research, www.ocerints.org, Istanbul, Turkey, 2018, pp. 111-119, ISBN: 978-605-82433-4-7.

Terziev, V., Stefanov, S., Banabakova, V. (2018d). Implementattion of the common european security and defence policy in the context of its military aspect. // ADVED 2018- 4th International Conference on Advances in Education and Social Sciences Abstracts \& Proceedings, 15-17 October 2018- Istanbul, Turkey, International Organization Center of Academic Research, www.ocerints.org, Istanbul, Turkey, 2018, pp. 120-131, ISBN: 978-605-82433-4-7.

Terziev, V., Stefanov, S., Banabakova, V. (2018e). Common european security and defence policy. // ADVED 2018- 4th International Conference on Advances in Education and Social Sciences Abstracts \& Proceedings, 15-17 October 2018- Istanbul, Turkey, International Organization Center of Academic Research, www.ocerints.org, Istanbul, Turkey, 2018, pp. 132-148, ISBN: 978-605-82433-4-7.

Terziev, Venelin. (2018f). Bulgarian experience in the development of social adaptation of military personnel, discharged from military service and their families. // ADVED 2018- 4th International Conference on Advances in Education and Social Sciences Abstracts \& Proceedings, 15-17 October 2018- Istanbul, Turkey, International Organization Center of Academic Research, www.ocerints.org, Istanbul, Turkey, 
IJASOS- International E-Journal of Advances in Social Sciences, Vol. V, Issue 13, April 2019

2018, pp. 213-227, ISBN: 978-605-82433-4-7.

Terziev, Venelin. (2018g). Opportunities of aplication of a competence-based approach in social adaptation of militaries discharged of service. // ADVED 2018- 4th International Conference on Advances in Education and Social Sciences Abstracts \& Proceedings, 15-17 October 2018- Istanbul, Turkey, International Organization Center of Academic Research, www.ocerints.org, Istanbul, Turkey, 2018, pp. 237-247, ISBN: 978-605-82433-4-7.

Terziev, Venelin. (2018h). Possible aspects of occupational and psychological adaptation of the military, discharged from military service and their families to a new activity life cycle. // ADVED 2018- 4th International Conference on Advances in Education and Social Sciences Abstracts \& Proceedings, 1517 October 2018- Istanbul, Turkey, International Organization Center of Academic Research, www.ocerints.org, Istanbul, Turkey, 2018, pp. 256-265, ISBN: 978-605-82433-4-7.

Terziev, Venelin. (2018i). Realities of implementing the social adaptation process of military personnel, discharged form service in Bulgaria. // ADVED 2018- 4th International Conference on Advances in Education and Social Sciences Abstracts \& Proceedings, 15-17 October 2018- Istanbul, Turkey, International Organization Center of Academic Research, www.ocerints.org, Istanbul, Turkey, 2018, pp. 266-276, ISBN: 978-605-82433-4-7.

Terziev, V., Latyshev, O., Georgiev, M. (2018j). The warehousing as an element of army logistics system in conditions of arctics (from experience of bulgarianrussian cooperation). // ADVED 2018- 4th International Conference on Advances in Education and Social Sciences Abstracts \& Proceedings, 1517 October 2018- Istanbul, Turkey, International Organization Center of Academic Research, www.ocerints.org, Istanbul, Turkey, 2018, pp. 248-255, ISBN: 978-605-82433-4-7.

Glushkov, P., Simeonov, S., Georgiev, M. (2018k). Method of determination of the diurnal energy consumption of the cadets from the Vasil Levski National Military university. ADVED 2018- 4th International Conference on Advances in Education and Social Sciences Abstracts \& Proceedings, 1517 October 2018- Istanbul, Turkey, International Organization Center of Academic Research, www.ocerints.org, Istanbul, Turkey, 2018, pp. 88-92, ISBN: 978-605-82433-4-7.

Banabakova, V., Georgiev, M. (2017a). Problems and perspectives in Military professional education and realization of cadets in Bulgaria. // Journal of Innovations and Sustainability, Innovations and Sustainability Academy. 3, 2017, N 4, pp. 37-47, ISSN 2367-8127 (CD-ROM), ISSN 2367-8151 (online).

Banabakova, V., Georgiev, M. (2018I). Military professional forming of the cadets at Vasil Levski National Military University. // Proceedings of INTCESS2018- 5th International Conference on Education and Social Sciences 5-7 February 2018- Istanbul, Turkey, International Organization Center of Academic Research, www.ocerints.org, Istanbul, Turkey, 2018, pp. 462-467, ISBN : 978-605-82433-2-3.

Terziev, Venelin. (2017b). Opportunities and trends in the development and the improvement processes in the Bulgarian military educational system. // 3rd Central \& Eastern European LUMEN International Conference, New Approaches in Social and Humanistic Sciences NASHS 2017, Chisinau, Republic of Moldova, June 8-10, 2017, 2018, pp.517-528, ISSN (print): 2601 - 2510, ISSN (on-line): 2601 2529, ISSN-L: 2601 - 2510, ISBN: 978-1-910129-15-9.

Terziev, Venelin. (2017c). Opportunities for improving the efficiencyof the socialadaptation of servicemen discharged from military service in Bulgaria. // Catalogue of the scientific, educational and methodical literature presented by authors at the I-XXXIV All-Russian book exhibitions held by Academy of Natural History, Exposition on the Frankfurter Buchmesse 2017, XXVII, Moskow, Academy of Natural History, 2017.

Hristov, Neno. (2018m). European intervention initiative vs common European army. ADVED 2018- 4th International Conference on Advances in Education and Social Sciences Abstracts \& Proceedings, 1517 October 2018- Istanbul, Turkey, International Organization Center of Academic Research, www.ocerints.org, Istanbul, Turkey, 2018, pp. 277-282, ISBN: 978-605-82433-4-7.

Terziev, V., Nichev, N. (2017d). Research on the management skills and abilities acquired in the military education system. // CBU International Conference Book of Abstracts March 22-24, Prague, Czech Republic, Innovations in Science and Education, 2017, ISBN 978-80-88042-09-9, p.152.

Terziev, V., Nichev, N. (2017e). Research on the management skills and abilities acquired in the military education system. // CBU International Conference Proceedings 2017, March 22-24, Prague, Czech Republic, Innovations in Science and Education, 2017, SSN 1805-997X (Print), ISBN 978-80-88042- 
07-5 (Print edition), pp.846-850.

Terziev, V., Nichev, N. (2017f). Developing the readiness for the organizational activity of the cadets. // CBU International Conference Book of Abstracts March 22-24, Prague, Czech Republic, Innovations in Science and Education, ISBN 978-80-88042-09-9, p.164.

Terziev, V., Nichev, N. (2017g). Developing the readiness for the organizational activity of the cadets. // CBU International Conference Proceedings 2017, March 22-24, Prague, Czech Republic, Innovations in Science and Education, 2017, SSN 1805-997X (Print), ISBN 978-80-88042-07-5 (Print edition), pp.915-919.

Terziev, V., Madanski, V., Georgiev, M. (2017h). Offset implementation impact on technology transfer in Bulgaria. // Proceedings of ADVED 2017- 3rd International Conference on Advances in Education and Social Sciences 9-11 October 2017- Istanbul, Turkey, 2017, ISBN: 978-605-82433-0-9, pp.743-747.

Terziev, V., Madanski, V., Georgiev, M. (2017i). Offset as an economic operation and a trade practice. // Proceedings of ADVED 2017- 3rd International Conference on Advances in Education and Social Sciences 9-11 October 2017- Istanbul, Turkey, 2017, ISBN: 978-605-82433-0-9, pp.748-753.

Terziev, V., Nichev, N., Stoyanov, E., Georgiev, M. (2017j). A general principle of the development process of balanced scorecards as an instrument of control. // Proceedings of ADVED 2017- 3rd International Conference on Advances in Education and Social Sciences 9-11 October 2017- Istanbul, Turkey, 2017, ISBN: 978-605-82433-0-9, pp.690-694.

Terziev, V., Latyshev, O., Georgiev, M. (2017k). Building competencies for social work through continuing vocational training. // Proceedings of ADVED 2017- 3rd International Conference on Advances in Education and Social Sciences 9-11 October 2017- Istanbul, Turkey, 2017, ISBN: 978-605-82433-0-9, pp.754-772.

Terziev, V., Nikolay, N., Bogdanov, P. (2017I). Comparative analysis of the formation of military professional skills in the cadets to be trained in logistics specializations. // Proceedings of ADVED 2017- 3rd International Conference on Advances in Education and Social Sciences 9-11 October 2017- Istanbul, Turkey, 2017, ISBN: 978-605-82433-0-9, pp.671-677.

Terziev, V., Madanski, V. Kanev, D. (2017m). Entry opportunities in the Bulgarian military-educational system. // Sport, Education and Society, Taylor \& Francis, 22, 2017, N 8(2), Source Normalized Impact per Paper (SNIP): 1.459 SCImago Journal Rank (SJR): 1.005 Impact factor: 1.269 Ranking: 60/230 (Education \& Educational Research), 20/44 (Hospitality, Leisure, Sport and Tourism), 51/82 (Sport Sciences), Print ISSN: 1357-3322 Online ISSN: 1470-1243, pp.1331-1346.

Terziev, V., Madanski, V., Kanev, D. (2017n). Condition and capabilities of the military-educational system of the Republic of Bulgaria. // Sport, Education and Society, Taylor \& Francis, 22, 2017, N 8(2), Source Normalized Impact per Paper (SNIP): 1.459 SCImago Journal Rank (SJR): 1.005 Impact factor: 1.269 Ranking: 60/230 (Education \& Educational Research), 20/44 (Hospitality, Leisure, Sport and Tourism), 51/82 (Sport Sciences), Print ISSN: 1357-3322 Online ISSN: 1470-1243, pp.1355-1372.

Terziev, V., Madanski, V., Kanev, D. (2017o). Directions for improvement of the military-educational system and its contribution for strengthening national security and the defence of the country. // Sport, Education and Society, Taylor \& Francis, 22, 2017, N 8(2), Source Normalized Impact per Paper (SNIP): 1.459 SCImago Journal Rank (SJR): 1.005 Impact factor: 1.269 Ranking: 60/230 (Education \& Educational Research), 20/44 (Hospitality, Leisure, Sport and Tourism), 51/82 (Sport Sciences), Print ISSN: 1357-3322 Online ISSN: 1470-1243, pp.1380-1393.

Terziev, V., Madanski, V., Kanev, D. (2017p). Entry opportunities in the bulgarian military-educational system and ensuring of civil rights. // IJAEDU- International E-Journal of Advances in Education, 3, 2017, N 8 , e-ISSN:2411-1821, pp.396-415.

Terziev, Venelin. (2017q). The needs of continuing vocational training of social work specialists providing social services. // Proceedings of SOCIOINT 2017- 4th International Conference on Education, Social Sciences and Humanities 10-12 July 2017- Dubai, UAE, 2017, ISBN: 978-605-82433-1-6, pp.641-653.

Terziev, V., Nichev, N. (2017r). Analysis of the environment for military educational system functioning and its impact on the preparation of cadets for military professional activities in the republic of Bulgaria. // Proceedings of SOCIOINT 2017- 4th International Conference on Education, Social Sciences and Humanities 10-12 July 2017- Dubai, UAE, 2017, ISBN: 978-605-82433-1-6, pp.627-630.

Terziev, V., Madanski, V., Kanev, D. (2017s). Entry opportunities in the bulgarian military-educational system 
and ensuring of civil rights. // Proceedings of SOCIOINT 2017- 4th International Conference on Education, Social Sciences and Humanities 10-12 July 2017- Dubai, UAE, 2017, ISBN: 978-60582433-1-6, pp.575-594.

Terziev, Venelin. (2017t). National security of the republic of Bulgaria. // International Journal of Management and Applied Science, 3, 2017, N 4, ISSN: 2394-7926, pp.22-28.

Terziev, V., Nichev, N. (2017u). Research of the value orientation and structural peculiarities of management activitiesofcadets in the course of military professional training. // Proceedings of the VII International Academic Congress „Fundamental and Applied Studies in EU and CIS Countries” (United Kingdom, Cambridge, England, 26-28 February 2017), Cambridge University Press, 7, 2017, ISBN: 978-0-87583597-4, pp.646-658, Source Normalized Impact per Paper (SNIP): 5.192 SCImago Journal Rank (SJR): 5.186 Impact factor: 7.549 .

Terziev, V., Nichev, N. (2017v). Research of the motivation for management activities of cadets in the course of their military professional training. // Proceedings of the VII International Academic Congress "Fundamental and Applied Studies in EU and CIS Countries" (United Kingdom, Cambridge, England, 26-28 February 2017), Cambridge University Press, 7, 2017, ISBN: 978-0-875-83597-4, pp.659-670, Source Normalized Impact per Paper (SNIP): 5.192 SCImago Journal Rank (SJR): 5.186 Impact factor: 7.549 .

Terziev, V., Madanski, V. (2017w). Guidelines for development of military education system in Bulgaria. // Proceedings of the VII International Academic Congress "Fundamental and Applied Studies in EU and CIS Countries" (United Kingdom, Cambridge, England, 26-28 February 2017), Cambridge University Press, ISBN: 978-0-875-83597-4, 7, 2017, pp.610-625, Source Normalized Impact per Paper (SNIP): 5.192 SCImago Journal Rank (SJR): 5.186 Impact factor: 7.549.

Terziev, V., Madanski, V. (2017x). Development of military education system in Bulgaria. // American Journal of Education, The University of Chicago Press, 2017, 123, 2017, N 4 (2), ISSN: 0195-6744, pp.917937, Source Normalized Impact per Paper (SNIP): 1.653, SCImago Journal Rank (SJR): 2.243. 